\title{
Democracy and Politics: An Introduction to the Special Issue of the Athens Journal of Social Sciences
}

\author{
By Gregory T. Papanikos*
}

\begin{abstract}
This paper is an introduction to the special issue of the Athens Journal of Social Sciences on Politics. It includes six papers, which relate to various aspects of politics in today's democracies. The first paper examines populism in selecting political parties of the European Union (EU); the second explains a political experiment performed in USA; the third discusses the prospects of the 2022 elections in Brazil; the fourth states that democracies need leaders as this is the case with Israel; the fifth looks at a real threat to democracy which is radicalism and violence using the case of the Slovakian youth; and the last paper examines a case of primary elections of a Greek political party (PASOK).
\end{abstract}

Keywords: politics, democracy, elections, Brazil, Greece, Israel, Slovakia, USA, European Union, Latin America

\section{Introduction}

This note is an introduction to the special issue on politics of the Athens Journal of Social Sciences. It includes six papers; some of them were presented at ATINER's international conferences; the other papers were independent submissions. All papers have been blindly peer reviewed and accepted for publication. The six papers refer to different countries/areas: European Union (EU), USA, Brazil and Latin America, Israel, Slovakia and Greece.

What is common in all these countries? Democracy, which in the contemporary world, means elections. These elections are related to choosing a representative such as a president; they do not include voting on an issue. This is the reason this type of democracy is called representative democracy. Otherwise, if people were to vote on each specific issue, it would then be called direct democracy.

In Papanikos (2020, 2022a, 2022b), I have demonstrated that a representative democracy is different from the democracy practiced in Ancient Athens, and of course far from an ideal democracy discussed by Plato, John Stuart Mills and John Dewey. All these authors emphasized the role of education as a prerequisite for a well-functioning democracy. However, democracy is not a static concept, and in different countries and time periods, is practiced in different ways. For example, the system of democracy practiced in the USA is different from the one experienced in the countries of the EU.

All democracies can be evaluated on how "democratic" they are using five criteria presented in Papanikos (2022a): isegoria (freedom of speech); isonomy

*President, Athens Institute for Education and Research, Greece; Honorary Professor of Economics, University of Sterling, UK; and Professor, MLC Ljubljana, Slovenia. 
(equal before the law); isocracy (equal probability of being elected as an archon); isoteleia (taxes according to ability to pay) and isopoliteia (democracies should treat other states fairly).

The six papers presented in this special issue of the Athens Journal of Social Sciences echo these five criteria as I will demonstrate in this introductory paper by presenting each one of them in the separate sections of this note.

\section{Populism Cannot be avoided in Democracies}

Despite the differences in the practice of democracy it seems that populism cannot be avoided. The first paper of this special issue discusses populism in the countries of the EU. Since the times of Pericles in Ancient Athens, populism is a characteristic of democracy. One may give the following definition of democracy: democracy exists when populism is thriving. Only in countries that do not have democracy, populism is dead along with many dissidents. In Ancient Athens, Plutarch informs us, Pericles (even though he was losing), was able to persuade the Athenian public to cheer him as a winner through his populist rhetoric-the apotheosis of populism. In modern Greece, as in many other countries, this has survived as long as they have some kind of a democracy.

Colonescu (2022) discusses the issue of populism in a sample of political parties of the EU. As an instrument of his analysis, he used expert evaluations of the Chapel Hill Expert Survey (CHES) 2017 data. A number of measures are used to differentiate between political parties: a party's stance (left-right) on economic matters; a party's stance on general matters, not only economic; a party's position from green, alternative, and libertarian at the lower end of the scale to traditional, authoritarian, and nationalist at the highest end; a party's position towards the European Union project; etc. He uses factor-analysis to identify similarities among the 26 variables, which represent a measure of populism.

His model shows, with a high degree of accuracy, that political parties in the EU can be classified into three groups: non-populist parties, left-populist, and right-populist. He concludes that his research, “... reveals, surprisingly sometimes, less understood features of some parties; it provokes reflection on the various shades of gray surrounding some political parties that are, otherwise, in the very spotlight of today's European politics."

\section{Party Orientation: An Experiment from the USA}

Al Marrar and Allevato (2022) examined whether political alignment along the lines of Republicans/Conservatives and Democrats/Liberals cause a "selective attention bias". Their sample consisted of 117 participants from the USA who were asked to read a political article on a social issue which was favorable to Democrats. Then, the participants were asked to recollect as much information as possible by typing it into a text box. Additionally, participants were asked to rate the article of how they felt reading it: neutral, positive or negative. 
One would have predicted Democrats will recall more positive information and positive effects than the Republicans from reading the article, but the authors found the opposite. They concluded that it is very difficult for voters to think outside the box.

I find the article very important because democracy relates to education. Since the Hesiodic times, education relates to memory. It is not an accident that the mother of the nine muses (protectors of arts and sciences in ancient Greece) was Mnemosyne (memory).

A better democracy requires better-educated voters; people who read and write is a necessary, but not a sufficient condition. Reading an article and recalling the message it portrays is a key issue for democracy. How people process this information becomes an integral part of the democratic process and is the necessary condition for a better democracy. My recollection of the information provided in the paper is that it contributes to this important literature.

\section{Elections in Brazil}

In October 2022 Brazil is heading into another election. The prospects of these elections are analyzed by De Caria Patrício (2022). She examines the current and the past of the Brazilian political process, but she extends her analysis to Latin American countries in general; a political relationship that goes back to the $19^{\text {th }}$ century. She concentrates on the two frontrunners as this is currently shown in the polls: (a) the current President Bolsonaro and (b) the ex-President Lula. The latter candidate is running first in the polls at the time that the paper was written (December 2021).

The author gives an excellent presentation of the facts which can explain the win of Bolsonaro in the previous elections and his demagogue and populism which is his characteristic style. Nevertheless, he commands a high rate of acceptance among Brazilian voters.

On the other hand, Lula is returning as a frontrunner in the polls, but his public image has been shattered by the allegations of embezzlement.

Both are considered populists by the author and if either win, Brazil's future looks dismal. The author emphasizes the international image of Brazil, which has been deteriorated due to Bolsonaro's response to the pandemic of COVID-19. She suggests that Brazil needs a moderate president which will reestablish Brazil's image in international relations.

\section{Democracy Needs Leaders: The Case of Benjamin Netanyahu in Israel}

Ever since the Ancient Athenian democracy, political leaders put their stamp on the quality of democracy. This was the case in the previous paper in Brazil. The next paper in this special issue looks at another well-known leader in the international area; that of Benjamin Netanyahu of Israel. Buskila et al. (2022) 
examine Netanyahu's political personality. The emphasis of the authors was on emotional intelligence.

Their analysis is based on a questionnaire, which was sent out to 411 Israeli voters with at least an academic degree. The perception of the participants of the study thought highly (a score of 5.06 with a maximum of 7) of Benjamin Netanyahu. Thus, the authors conclude that Israeli citizens perceive Netanyahu as a smart, intelligent and shroud politician.

According to the authors, this evidence does not support the thesis that emotional intelligence has only positive sides. It can be interpreted that leaders with emotional intelligence may use this skill to manipulate others to meet their personal political objectives.

A similar conclusion was reached by Plutarch about Pericles who ruled the city-state of Athens in the fifth century BCE.

\section{Radicalism is a Serious Threat to Democracy: The Case of Slovakia}

Populism is a problem that all democracies face. If it is kept within the limits of the framework of checks and balances set by a democratic society, then it cannot undermine democracy itself even though it undermines its effectiveness. Populism has no real future in a democracy unless it turns into radicalism which uses violence.

Brutovská and Béreš (2022) address this issue of youth radicalism in Slovakia. Their approach is empirical and is based on a qualitative probe among young people aged 14-17 years. One of the characteristics of radicals is their mistrust for parliamentary democracy. They also think that the state is unable to solve the modern problems of society. During the recent crises in Europe of the Great Recession and immigration, extremism (which included violence) was reappearing in many European countries.

This is a typical attitude of radicalism which is developed in a democracy. It reminds me of the rebellious Alcibiades, who, in his youth, resulted to violence to achieve political means. However, and contrary to the study's results, Alcibiades and other Athenian youth at the time belonged to upper class, whose members were well-educated as was Alcibiades himself.

I do believe that a strong democracy can tolerate rebellious and radical youth as long as the process of socialization is such that sooner or later the aspirations of the youth are aligned with the aspirations of a truly democratic society.

\section{An Example of Primary Elections: The Case of PASOK (Greece)}

The last paper is about primary elections in Greece (Papanikos 2022c). The author uses the case of PASOK to analyze all previous elections of party leaders going back to 1996. PASOK was the first political party to implement such a primary electoral system. A few years later the opposition party, New Democracy, 
adopted such a system. Primary elections are an integral part of contemporary representative democracies.

The author reviews the relevant literature of primary elections systems. Three are identified in the literature. Firstly, the partisan system where only party members vote. Secondly, a system that party members and friends vote to elect the party leader and other party representatives. Thirdly, a blanket system whereby all eligible voters can vote, including the members of other parties.

The author focuses his analysis in the most recent primary elections of December 2021. An emphasis is given on the ideology of the candidates, but other factors played a significant role, such as the disappointing campaign of ex-leader and ex-prime minister who was frontrunner, but he came second in the first round and lost the primary elections in the second round.

His failure is further analyzed in the paper by arguing that he failed to mobilize his own supporters. One explanation may be given by the first paper of this issue. Populists may appeal once, but they are usually not attractive the second time who test their political chances.

\section{Conclusions}

The overall conclusion that emerges from these studies is that democracy is not an ideal political system. Many have envisaged political systems that resemble a paradise on earth. Democracy is a continuous struggle and countries with a true democracy can tolerate and absorb extreme behaviors such as populism and radicalism.

After all, the best indicator that a country has a democracy is that any citizen can openly questions its existence without any direct or indirect repercussionsthis is the essence of democracy, and the six papers presented in this special issue is a testimony to this principle. All six countries have a democratic system of organizing their political affairs. In a nutshell, this system was defined by Pericles that the "many rule". Until a better practical political system is found, democracy is second to none from all the implemented systems of ruling a politeia.

\section{References}

Al Marrar M, E Allevato (2022) Cognitive dissonance: affecting party orientation and selective recall of political information. Athens Journal of Social Sciences 9(2): 115-140.

Buskila Y, Chem Levi T, Kayne A (2022) "If you rake me over the coals..." The emotional intelligence of Benjamin Netanyahu: the Prime Minister of Israel, as perceived by Israeli citizens. Athens Journal of Social Sciences 9(2): 181-200

Brutovská G, M Béreš (2022) How do revolting young people become radicals The case of Slovakia. Athens Journal of Social Sciences 9(2): 161-180. 
Colonescu C (2022) Measures of populism in the CHES 2017 dataset. Athens Journal of Social Sciences 9(2): 95-114.

De Caria Patrício R (2022) Brazil: country on hold, political tension running high. Athens Journal of Social Sciences 9(2): 141-160.

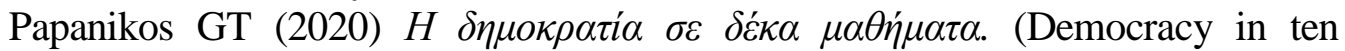
lessons). Athens: Athens Institute for Education and Research (ATINER).

Papanikos GT (2022a) The five ancient criteria of democracy: the apotheosis of equality. Athens Journal of Humanities \& Arts (forthcoming).

Papanikos GT (2022b) The bright future of democracy is in education. Athens Journal of Education 9(2):187-198. https://bit.ly/3sJGsoN

Papanikos GT (2022c) The use of primaries by political parties: the case of PASOK. Athens Journal of Social Sciences 9(2): 201-222. 
Athens Journal of Social Sciences- Volume 9, Issue 2, April 2022 - 89-110 